\title{
CREVASSE DEFORMATION AND EXAMPLES FROM ICE STREAM B, WEST ANTARCTICA
}

\author{
(Abstract) \\ by \\ P.L. Vornberger *† and I.M. Whillans*** \\ (The Ohio State University, * Byrd Polar Research Center, and ** Department of Geology and \\ Mineralogy, 125 South Oval Mall, Columbus, OH 43210, U.S.A.)
}

\begin{abstract}
Crevasses are subject to rotation and bending according to the velocity field through which they travel. The objective of this study is to determine to what extent the velocity field can be inferred from measurements of the resulting shapes of crevasses.

A quantitative model of crevasse deformation is developed, based on the following assumptions: (1) each crevasse is assumed to open perpendicularly to the principal extensional regional strain-rate, (2) the crevasse forms when the principal extensional strain-rate exceeds some specified critical value, and (3) velocity gradients are constant over the area of interest. The first two assumptions are reasonable and the third is necessary for an analytic solution of flow trajectories. The crevasse is carried along, rotated, and bent, and may continue to increase in length. Calculations are made for different velocity fields, and velocity fields are sought that produce crevasses similar to those found in three different areas of Ice Stream B.

Hook-shaped crevasses occur just outside the chaotic zone at the ice-stream margin. These are similar to the curved marginal crevasses of ten found in the accumulation zone of valley glaciers. They are successfully modelled by combining strong lateral shear with slow flow of ice from the ice ridge into the ice stream. The curvature at the most sharply bent part of the crevasse is found to be a useful measure and, together with measurements of ice flow from the ridge, can be used to infer the rate of lateral shear. This rate compares favorably with the single measurement obtained so far (Bindschadler and others 1987).

A pattern of splaying crevasses develops on the ice
\end{abstract} stream down-glacier of its narrowest part. These crevasses are similar to longitudinal crevasses found in the ablation zone of many valley glaciers. Models with linear variation in velocity cannot reproduce the observed pattern. However, we have been able to simulate higher-order variations by joining together successive linear models. The observed crevasse pattern is successfully produced if the side shearing varies as the third power of distance from the center of symmetry of the crevasse pattern. Such a variation is expected for a linear gradient in side-drag stress and a third-power constitutive relation for ice. The observed crevasse pattern is thus consistent with side drag varying linearly across the ice stream.

The third example is the rotation of transverse crevasses, which occur in trains on the main part of the ice stream. This rotation is due to side shearing but its magnitude is also affected by turning of the flow line and by normal strain-rates. It is therefore possible to reproduce the observed pattern for a wide range of velocity fields, and so measurements of the orientation of transverse crevasses provide only an upper limit on side shearing within the main body of the ice stream.

There are many other examples of crevasse patterns on Ice Stream B and on other glaciers that can be studied in this way. We propose that important constraints can be placed on velocity gradients and on the flow dynamics by using quantitative modelling of crevasse shapes.

\section{REFERENCE}

Bindschadler, R.A., S.N. Stephenson, D.R. MacAyeal, and S. Shabtaie. 1987. Ice dynamics at the mouth of Ice Stream B, Antarctica. J. Geophys. Res., 92(B9), 88858894.
† Present address: Science Applications Research, 4400 Forbes Boulevard, Lanham, MD 20706, U.S.A. 